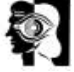

columns

\title{
miscellany
}

\section{Request for information on Dr Edward Mapother (1881-1940)}

Dr Edgar Jones, Reader in the History of Medicine and Psychiatry is currently researching the important role played by
Dr Edward Mapother as medical superintendent of the Maudsley Hospital from 1923 until his retirement in 1939, with a view to publication. Any information regarding Dr Mapother's professional papers would be valued. In addition, contact from any retired psychiatrists who knew Dr Mapother and would be willing to be interviewed would be appreciated. Further information about the project can be obtained from Dr Edgar Jones, Reader in the History of Medicine and Psychiatry, Department of Psychological Medicine, Guy's, King's and St Thomas' Medical School, 103 Denmark Hill, London SE5 8AZ (e-mail: E.Jones@hogarth7.demon.co.uk).

\section{forthcoming events}

Organised by the Belmont Postgraduate Psychiatric Centre at Sutton Hospital, Surrey, the 59th Residential Revision Course for the MRCPsych Examination will be held on 3-10 April 2002 (Part I) and 10-18 April 2002 (Part II) at the University of Surrey, Guildford. Further details can be obtained from Mrs S. Caines, Belmont Postgraduate Centre, Chiltern Wing, Sutton Hospital, Sutton, Surrey SM2 5NF (tel: 0208296 4177).

The City of Oslo Children and Family Authority Centre for Child and Adolescent Psychiatry is the organiser of Psychotic Disorders in Childhood and Adolescence, a conference that will take place in Oslo, Norway, on 27-28 May 2002. Speakers have been invited from the US (Fred R. Volkmar, Gabrielle A. Carlson), England (Paul Harrison) and Germany
(Helmut Remschmidt). Further details are available from Dr Ingrid Spurkland, Centre for Child and Adolescent Psychiatry, PO Box Vinderen, N-0319 Oslo, Norway (tel: +47 234922 40; fax: +47 234923 02; e-mail: ingrid.spurkland@psykiatri. uio.no).

Midland Course in Group Work with Children and Adolescents 2002. This non-residential course is for professionals who are interested in group work with children and adolescents, whether they are beginners or have already have experience of group work. The course will be held in Northampton over 3 weekends: 1-2 June 2002, 15-16 June 2002 and 29-30 June 2002. For further information and application forms please contact: Dr Kedar Dwivedi, Course
Director, c/o 1 Becket Way, Northampton NN3 6EX (tel: 01604604 608; fax: 01604604 531; e-mail: Kedar.Dwivedi @ngh-tr.anglox.nhs.uk).

The National Autistic Society in partnership with the Autism Research Centre, University of Cambridge, is hosting a 2day international conference to be held in London on 6-7 September 2002. Entitled A World of Difference, the conference will feature keynote speeches from international experts on the condition from the UK, Sweden and the US. The event is aimed at professionals, researchers and parents of people with autistic spectrum disorder. Further details about the conference can be obtained at the following designated website: http:// www.autism2002.com 